JIME (Journal of Industrial and Manufacture Engineering), ), 4 (1) Mei 2020

ISSN 2549-6328 (Print)ＩSSN2549-6336 (Online) DOI : 10.31289/jime.4vi1.3242

JIME (Journal of Industrial and Manufacture Engineering)

Available online http://ojs.uma.ac.id/index.php/jime

Email: jime@uma.ac.id

\title{
Analisa Postur Kerja pada Aktivitas Pengujian Pegas dengan Menggunakan Metode OWAS
}

\author{
Juarni*1) dan Marwin Ramadhan ${ }^{2)}$ \\ Teknik Industri, Fakultas Teknologi Industri, Institut Teknologi Medan, Indonesia \\ Diterima: Januari 2020; Disetujui: Januari 2020; Dipublikasi: Mei 2020; \\ * Corresponding author: Juarni@itm.ac.id
}

\begin{abstract}
Abstrak
Perbaikan postur kerja penting dilakukan untuk menjaga kenyamanan pekerja dalam melakukan aktivitas kerja. Pada aktivitas pengujian pegas di PT. Kereta Api Indonesia (Persero) Divisi Regional I Sumatera Utara Upt. Balai Yasa Pulubrayan, operator mengangkat pegas seberat $\pm 10-20$ kg saat melakukan aktivitas pengujian pegas. Pada saat melakukan aktivitas pengujian pegas bila tidak dilakukan dengan benar akan menyebabkan cedera pada system musculoskeletal bagi pekerja. Ovako Work Analisys System (OWAS) merupakan suatu metode untuk mengevaluasi dan menganalisa sikap kerja dari operator yang diamati, yang meliputi posisi punggung, lengan, kaki dan berat beban. Metode ini dapat mengidentifikasi sikap kerja yang berpotensi menimbulkan kecelakaan kerja pada systemmusculoskeletal berdasarkan penilaian kategori resiko dan tindakan perbaikan. Tujuan dari penelitian ini adalah untuk memperbaiki dan menentukan apakah postur kerja pada aktivitas pengujian pegas aman atau tidak pada system musculoskeletal. Berdasarkan hasil pengolahan data dengan menggunakan metode OWAS, dari 33 postur kerja didapatkan bahwa postur kerja yang aman pada system musculoskeletal berjumlah 24 postur kerja dan postur kerja yang memiliki resiko pada system musculoskeletal berjumlah 9 postur kerja.

Kata kunci : Metode OWAS, Pegas, Postur Kerja, System Musculoskeletal.
\end{abstract}

How to Cite: Juarni, Ramadhan, M (2020), Analisa Postur Kerja pada Aktivitas Pengujian Pegas dengan Menggunakan Metode OWAS, JIME (Journal of Industrial and Manufacture Engineering), 4(1) : 43-52 
Juarni, Ramadhan, M, Analisa Postur Kerja pada Aktivitas Pengujian Pegas dengan Menggunakan Metode OWAS

\section{PENDAHULUAN}

PT. Kereta ApiIndonesia (Persero) Divisi Regional I Sumatera Utara Upt. Balai Yasa Pulu Brayan merupakan perusahaan yang bergerak di bidang produksi perbaikan kereta gerbong, kereta penumpang, lokomotif dan perakitan bogie kereta api. Dalam melakukan perbaikan pasti membutuhkan peranan manusia sebagai sumber tenaga kerja. Peranan manusia sebagai sumber tenaga kerja masih dominan dalam menjalankan proses produksi terutama kegiatan yang bersifat manual. Salah satu peranan manusia di dalam bekerja adalah pada aktivitas pemindahan material secara manual. Tetapi pemindahan material secara manual apabila tidak dilakukan secara ergonomis akan menimbulkan kecelakaan dalam bekerja, yang disebut juga "Over exertion-lifting and carrying" yaitu kerusakan jaringan tubuh yang diakibatkan oleh beban angkat yang berlebihan (Nurmianto, 2004)

Pada PT. Kereta Api Indonesia (Persero) Divisi Regional I Sumatera Utara Upt. Balai Yasa Pulu Brayan salah satu pekerjaan yang dilakukan secara manual adalah pada aktivitas pengujian pegas. Pada aktivitas pengujian pegas pekerja dihadapkan pada aktivitas yang berkaitan dengan mengangkat, menurunkan, membawa serta memindahkan material baik pada kondisi tubuh pada saat berjalan, membungkuk, memutar dan sebagainya. Namun aktivitas membungkuk dan memutar didalam tempat kerja saat melakukan pekerjaan secara manual seharusnya dikurangi atau bahkan jika memungkinkan aktivitas ini sebaiknya dihilangkan karena sikap ini rawan yang dapat menimbulkan gangguan pada sistem musculoskeletal. Dari latar belakang inilah penulis mengambil judul “Analisa Postur Kerja Pada Aktivitas Pengujian Pegas Dengan Menggunakan Metode OWAS di PT. Kereta Api Indonesia (Persero) Divisi Regional I Sumatera Utara Upt. Balai Yasa Pulu Brayan"

\section{METODE PENELITIAN}

Interaksi yang sering dilakukan dalam sistem kerja adalah interaksi antara manusia dengan mesin. Hubungan ini sering disebut sebagai interaksi manusia-mesin (human-machine system). Wujud hubungan ini dapat berupa kombinasi satu atau lebih manusia dengan satu atau lebih komponen fisik untuk saling berinteraksi. Sedangkan kegiatan yang dilakukan oleh interaksi manusia-mesin adalah proses input, operasi dan hasil output yang diinginkan.

Disiplin ilmu ergonomi merupakan suatu disiplin yang membahas tentang interaksi antara manusia-mesin. Disiplin ilmu ergonomi mulai dicetuskan secara formal pada tahun 1949, akan tetapi aktivitas yang berkenaan dengannya, telah bermunculan puluhan tahun sebelumnya. Istilah ergonomi berasal dari bahasa Yunani yaitu “Ergon" (kerja) dan “ Nomos" (hukum) atau yang berarti ilmu yang mempelajari tentang hukum-hukum kerja. Dengan demikian ergonomi adalah suatu sistem yang berorientasi kepada disiplin ilmu, yang sekarang diterapkan pada hampir semua aspek kehidupan atau kegiatan manusia (Tarwaka, 2010 Harapan Press, Solo).

Manual handling didefenisikan sebagai suatu pekerjaan yang berkaitan dengan mengangkat, menurunkan, mendorong, menarik, menahan, membawa atau 
memindahkan bahan dengan satu tangan atau kedua tangan dan atau dengan pengerahan seluruh badan. Dan selama tenaga manusia masih diperlukan untuk mengangkat, menarik, menahan, membawa atau memindahkan beban, maka hal tersebut masih dalam rentang defenisi manual handling.

Faktor-faktor yang dominan yang berkaitan dengan terjadinya cidera akibat pekerjaan manual handling antara lain meliputi :

1. Sikap tubuh yang tidak alamiah dan dipaksakan (seperti : badan membungkuk dan memuntir ke samping, jongkok, berlutut, dll).

2. Gerakan berulang (seperti:sering menjangkau, mengangkat, membawa objek kerja).

3. Pengerahan tenaga yang berlebihan (seperti : membawa atau mengangkat objek kerja yang terlalu berat).

4. Sikap kerja statis (seperti : harus mempertahankan sikap diam untuk waktu yang lama pada satu jenis aktivitas).

Pegas merupakan suatu komponen yang mempunyai fungsi untuk meredam dan mengurangi getaran dan kejutan yang diakibatkan oleh kondisi lintasan yang bergelombang, berlubang dan tidak rata agar tidak tersalur ke rangka kendaraan.

Pegas pada sistem suspensi mempunyai beberapa tipe yang umum dipakai adalah pegas ulir (coil spring), pegas daun (leafspring), dan pegas (torsion bar spring). Pegas yang akan diangkat sebagai objek penelitian yaitu :
1. Ukuran dan Bentuk Pegas

Ukuran pegas yang baik yaitu memiliki tinggi $44 \mathrm{~cm}$ ketika belum di beri beban. Pegas yang memenuhi syarat adalah pegas yang mampu kembali ke bentuk atau tinggi seperti semula setelah di berikan pembebanan dan tidak melewati batas maksimum toleransi yaitu $18 \mathrm{~mm}$.

Pegas yang biasa dipakai untuk kereta api adalah pegas ulir (coil spring). Seperti gambar di bawah ini :



Gambar 1. Pegas Ulir

\section{Berat Pegas}

Pada saat melakukan riset, saya melakukan pertanyaan tentang pegas. Dan mengetahui bahwa pegas yang ada di Balai Yasa Pulu Brayan memiliki berat 10-20 $\mathrm{kg}$.

\section{Teknik Pengangkatan}

Pengangkatan pegas di Balai Yasa Pulu Brayan pada saat pengujian dilakukan secara manual. Jarak dari tumpukan pegas ke tempat pengujian berkisar \pm 3 meter.

\section{Jenis Pegas}

Pada sistem suspensi kereta api terdapat tiga jenis pegas yaitu pegas dukung, pegas ayun dalam dan pegas ayun luar. Di Balai Yasa terdapat beberapa jenis pegas berdasarkan tipe bogienya, seperti pegas dukung dengan tipe bogie $\mathrm{K} 5$, K7 dan KD3 dan pegas ayun dalam dan luar dengan tipe bogie K5, K7 dan KD3. 
Juarni, Ramadhan, M, Analisa Postur Kerja pada Aktivitas Pengujian Pegas dengan Menggunakan Metode OWAS

5. Bahan Pegas

Pegas terbuat dari baja atau disebut baja pegas. Baja pegas sebenarnya tidak mempunyai kekerasan yang tinggi sebagai sifat utamanya. Sifat utama dari baja pegas yang di pakai adalah elastisitasnya. Bahan baja pegas yang digunakan diimpor dari jepang, yaitu dari aichi steel work, ltd. Baja pegas yang digunakan adalah memakai standard JIS (Japanise Industrial Standards).

Baja pegas yang digunakan adalah jenis SUP 9, komposisi kimia dari baja pegas SUP 9 adalah sebagai berikut :

C $\quad: 0,52-0,60 \%$

Si $\quad: 0,15-0,35 \%$

Mn : $0,65-0,95 \%$

$\mathrm{P}:$ : 0,035 max

S : : 0,035 max

$\mathrm{Cr} \quad: 0,65-0,95 \%$

Keluhan pada sistem musculoskeletal adalah keluhan pada bagian-bagian otot rangka yang dirasakan oleh seseorang mulai dari keluhan sangat ringan sampai sangat sakit. Apabila otot menerima beban statis secara berulang dan dalam waktu yang lamaakan dapat menyebabkan keluhan berupa kerusakan sendi, ligamen dan tendon. Keluhan hingga kerusakan inilah yang biasanya diistilahkan dengan keluhan musculoskeletal disorders (MSDs) atau cidera pada sistem musculoskeletal. Apabila pekerjaan berulang tersebut dilakukan dengan cara yang nyaman, sehat dan sesuai dengan standar yang ergonomis, maka tidak akan menyebabkan gangguan musculoskeletal dan semua pekerjaan akan berlangsung dengan efektif dan efisien.

Sikap kerja yang sering dilakukan oleh manusia dalam melakukan pekerjaan antara lain berdiri, duduk, membungkuk, jongkok, berjalan dan lain-lain. Sikap kerja tersebut dilakukan tergantung dari kondisi dalam sistem kerja yang ada. Jika kondisi sistem kerjanya yang tidak sehat akan menyebabkan kecelakaan kerja, karena pekerja melakukan pekerjaan yang tidak aman. Sikap kerja yang salah, canggung dan diluar kebiasaan akan menambah resiko cidera pada bagian musculoskeletal.

\section{Sikap Kerja Berdiri}

Sikap kerja berdiri merupakan salah satu sikap kerja yang sering dilakukan ketika melakukan sesuatu pekerjaan. Berat tubuh manusia akan ditopang oleh satu ataupun kedua kaki ketika melakukan posisi berdiri. Aliran beban berat tubuh mengalir pada kedua kaki menuju tanah. Hal ini disebabkan oleh faktor gaya gravitasi bumi. Kestabilan tubuh ketika posisi berdiri dipengaruhi oleh posisi kedua kaki. Kaki yang sejajar lurus dengan jarak sesuai dengan tulang pinggul akan menjaga tubuh dari tergelincir. Selain itu perlu menjaga kelurusan antara anggota tubuh bagian atas dengan anggota tubuh bagian bawah. Sikap kerja berdiri memiliki beberapa permasalahan system musculoskeletal. Nyeri punggung bagian bawah (low back pain) menjadi salah satu permasalahan posisi sikap kerja bediri dengan sikap punggung condong ke depan.

\section{Sikap Kerja Membungkuk}

Salah satu sikap kerja yang tidak nyaman untuk diterapkan dalam pekerjaan adalah membungkuk. Posisi ini tidak menjaga kestabilan tubuh ketika bekerja. Pekerja mengalami keluhan rasa nyeri pada bagian punggung bagian bawah (low back pain) bila dikukan secara berulang dan periode yang cukup lama. Pada saat 
membungkuk tulang punggung bergerak ke sisi depan tubuh. Otot bagian perut dan sisi depan invertebratal disk pada bagian lumbar mengalami penekanan. Pada bagian ligamen sisi belakang dari invertebratal disk justru mengalami peregangan atau pelenturan. Kondisi ini akan menyebabkan rasa nyeri pada punggung bagian bawah.

\section{Pengangkatan Beban}

Kegiatan ini menjadi penyebab terbesar terjadinya kecelakaan kerja pada bagian punggung. Pengangkatan beban yang melebihi kadar dari kekuatan manusia menyebabkan penggunaan tenaga yang lebih besar pula atau over exertion. Adapun pengangkatan beban akan berpengaruh pada tulang belakang bagian lumbar. Pada wilayah ini terjadi penekanan pada bagian L5/S1 (lempeng antara lumbar ke-5 dan sacral ke-1). Penekanan pada daerah ini mempunyai batas tertentu untuk menahan tekanan. Invertebratal disk pada L5/S1 lebih banyak menahan tekanan daripada tulang belakang. Bila pengangkatan yang dilakukan melebihi kemampuan tubuh manusia, maka akan terjadi disk herniation akibat lapisan pembungkus pada invertebratal disk pada bagian L5/S1 pecah.

\section{Membawa Beban}

Terdapat perbedaan dalam menetukan beban normal yang dibawa oleh manusia. Hal ini dipengaruhi oleh frekuensi dari pekerjaan yang dilakukan. Faktor yang paling berpengaruh dari kegiatan membawa beban adalah jarak. Jarak yang ditempuh semakin jauh akan menurunkan batasan beban yang dibawa.

Metode OWAS merupakan sebuah metode yang sederhana dan dapat digunakan untuk menganalisa suatu pembebanan pada postur tubuh. Aplikasi metode OWAS didasarkan pada hasil pengamatan dari berbagai posisi yang diambil pada pekerja selama melakukan pekerjaannya, dan digunakan untuk mengidentifikasi sampai dengan 252 posisi yang berbeda. Metode OWAS mengkodekan sikap kerja pada bagian punggung (4 posisi), lengan (3 posisi), kaki (7 posisi), dan pembebanan (3 interval). Postur dasar OWAS disusun dengan kode postur kerja yang terdiri empat digit, dimana kode postur kerja tersebut disusun secara berurutan mulai dari punggung, lengan, kaki dan berat beban ketika melakukan aktivitas pekerjaan. Berikut ini adalah klasifikasi sikap bagian tubuh yang diamati untuk dianalisa dengan metode OWAS :

Sikap Punggung :

1. Lurus

2. Membungkuk

3. Memuntir

4. Membungkuk dan Memuntir

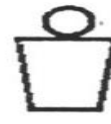

1

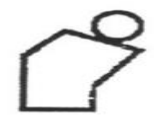

2

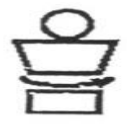

3

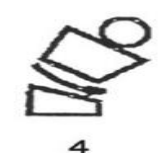
ggung
Sikap Lengan :

1. Kedua lengan berada dibawah ketinggian bahu

2. Salah satu lengan berada diatas ketingggian bahu

3. Kedua lengan berada diatas ketinggian bahu

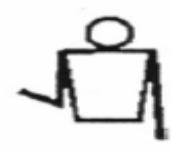

1

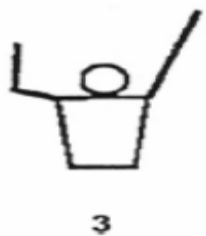

3 Gambar 3. Klasifikasi sikap lengan 
Juarni, Ramadhan, M, Analisa Postur Kerja pada Aktivitas Pengujian Pegas dengan Menggunakan Metode OWAS

Sikap Kaki :

1. Duduk

2. Berdiri dengan kedua kaki lurus

3. Berdiri dengan satu kaki lurus dan satu kaki menekuk

4. Berdiri dengan kedua lutut agak menekuk $<150^{\circ}$

5. Berdiri dengan kedua lutut agak menekuk $>150^{\circ}$

6. Berlutut

7. Berjalan

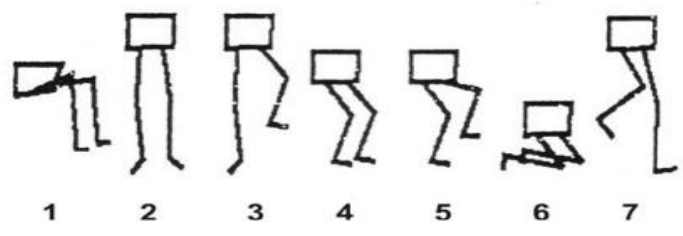

Gambar 4. Klasifikasi sikap kaki

Berat Beban :

1. Berat beban $<10 \mathrm{~kg}$

2. Berat beban $10 \mathrm{~kg} \mathrm{~s} / \mathrm{d} 20 \mathrm{~kg}$

3. Berat beban $>20 \mathrm{~kg}$

Dari masing-masing sikap kerja diatas, maka ditentukan pengkodean terhadap posisi sikap kerja berdasarkan sikap kerja bagian punggung, lengan, kaki dan berat beban pada saat melakukan aktivitas kerja, yang kemudian di lakukan klasifikasi sikap kerja berdasarkan tabel pengklasifikasian kategori resiko "kode posisi" OWAS sehingga kategori tingkat resiko pada saat melakukan aktivitas kerja dapat ditentukan.
Tabel 1. Pengklasifikasian kategori resiko "kode posisi" OWAS

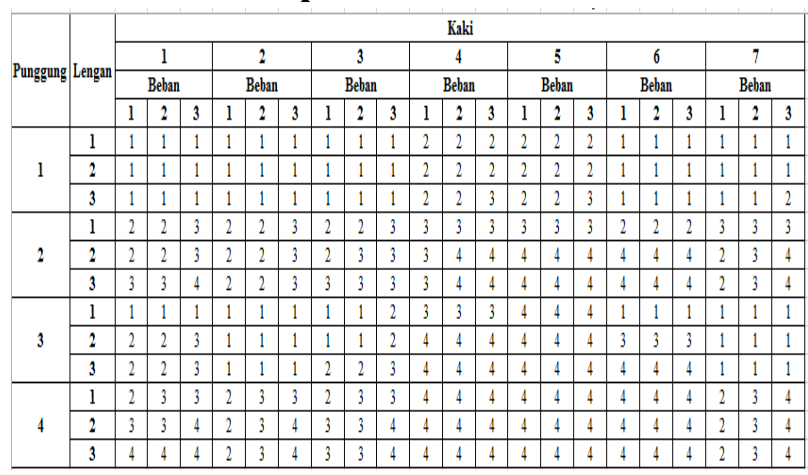

Tabel 2. Klasifikasi Tingkat Resiko Postur Tubuh menurut Frekuensi Relatif

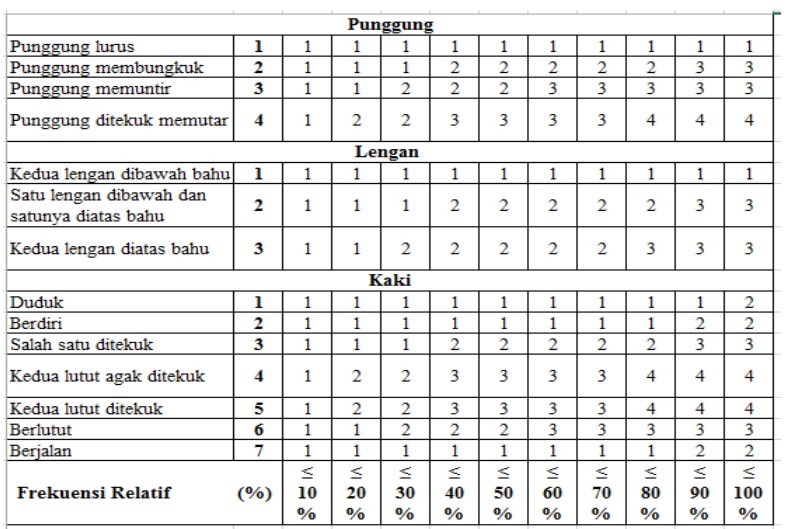

Hasil dari analisa postur kerja OWAS terdiri dari empat tingkat resiko berdasarkan pengklasifikasian kategori resiko dan tindakan perbaikan yaitu :

- Kategori dengan Tingkat Resiko 1 : Posisi normal tanpa efek yang dapat mengganggu sistem musculoskeletal. Tidak perlu perbaikan.

- Kategori dengan Tingkat Resiko 2 : Posisi yang berpotensi menyebabkan kerusakan pada sistem musculoskeletal. Tindakan perbaikan mungkin diperlukan.

- Kategori dengan Tingkat Resiko 3 : Posisi dengan efek berbahaya pada sistem musculoskeletal. Tindakan perbaikan diperlukan segera. 
- $\quad$ Kategori dengan Tingkat Resiko 4 : Posisi dengan efek sangat berbahaya pada sistem musculoskeletal.Tindakan perbaikan diperlukan sesegera mungkin.

\section{HASIL DAN PEMBAHASAN}

Data dilakukan ketika pekerja melakukan aktivitas pengujian pegas dengan cara mendokumentasikan aktivitas kerja tersebut kedalam bentuk foto-foto agar postur kerja dapat diamati dan dianalisa dengan metode yang digunakan (metode OWAS). Aktivitas pengujian pegas yang diamati dan dianalisa yaitu pengujian pegas dengan jenis Pegas Dukung K5, Pegas Ayun Dalam (inner) K5, dan Pegas Ayun Luar (outter) K5. Ketiga jenis pegas tersebut memiliki berat masing-masing yaitu :

1. Pegas Dukung K5 $: 14 \mathrm{~kg}$

2. Pegas Ayun Dalam (inner) K5 $: 12 \mathrm{~kg}$

3. Pegas Ayun Luar (outter) K5 : $20 \mathrm{~kg}$

Dari pengumpulan data diatas didapat 33 postur kerja yang harus dianalisa dengan menggunakan metode OWAS.

Adapun tahapan yang dilakukan dalam pengolahan data ini adalah :

1. Penentuan Postur Kerja dengan Metode OWAS

Data yang didapatkan dari pengumpulan data yaitu merupakan dokumentasi berupa foto postur kerja pada aktivitas pengujian Pegas Dukung K5, Pegas Ayun Dalam K5, dan Pegas Ayun Luar K5. Dari data tersebut maka dilakukan pengkodean postur kerja berdasarkan kode posisi sikap punggung, lengan, kaki dan berat beban.
2. Pengelompokkan postur kerja yang memiliki kode posisi sama.

Setelah dilakukan penentuan postur kerja dari setiap kode posisi pada aktivitas pengujian Pegas Dukung K5, Pegas Ayun Dalam K5 dan Pegas Ayun Luar K5, maka postur kerja yang memiliki kode posisi sama dikelompokkan menjadi satu untuk mempermudah pada saat dilakukan pengklasifikasian postur kerja berdasarkan kode posisi OWAS sehingga tidak terjadi perhitungan berulang.

3. Pengklasifikasian Postur Kerja Menggunakan Kode Posisi OWAS.

Setelah postur kerja yang memiliki kode sama dikelompokkan maka pengklasifikasian postur menggunakan kode posisi OWAS dapat dilakukan sehingga akan didapatkan penilaian hasil kategori resiko dari setiap kode postur kerja.

4. Pengklasifikasian postur kerja menurut frekuensi relatif.

Pada pengklasifikasian ini, frekuensi relatif dari setiap posisi seperti sikap punggung, lengan dan kaki dicari terlebih dahulu berdasarkan rumus yang ada, dan kemudian dilakukan penilaian sehingga didapat kategori resiko dari setiap posisi sikap punggung, lengan dan kaki.

Data postur kerja ketika dilakukan pengkodean dengan pengelompokkan kode yang sama : 
Juarni, Ramadhan, M, Analisa Postur Kerja pada Aktivitas Pengujian Pegas dengan Menggunakan Metode OWAS

Tabel 3. Kelompok kode postur kerja

\begin{tabular}{|c|c|c|}
\hline No & Kode Posisi & Jumlah \\
\hline 1 & 3122 & 3 \\
\hline 2 & 1172 & 6 \\
\hline 3 & 2132 & 6 \\
\hline 4 & 4122 & 1 \\
\hline 5 & 2122 & 2 \\
\hline 6 & 3132 & 6 \\
\hline 7 & 4142 & 1 \\
\hline 8 & 4132 & 1 \\
\hline 9 & 2142 & 5 \\
\hline 10 & 1122 & 1 \\
\hline 11 & 3142 & 1 \\
\hline \multicolumn{2}{|c|}{ Jumlah } & 33 \\
\hline
\end{tabular}

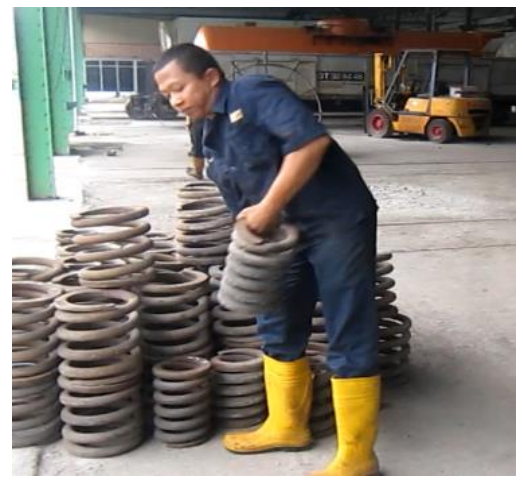

Gambar 5. Pengangkatan pegas

Aktivitas kerja diatas memiliki kode posisi 3122 yaitu dengan posisi :

- Punggung (3) : Memuntir

- Lengan (1) : Kedua lengan berada di bawah ketinggian bahu

- $\quad$ Kaki (2) : Berdiri dengan kedua kaki lurus

- $\quad$ Berat beban (2) : Berat beban $>10 \mathrm{~kg}$ s/d $20 \mathrm{~kg}$

Kode posisi postur kerja tersebut diklasifikasikan berdasarkan pengklasifikasian kategori resiko kode posisi OWAS, sehingga didapat seperti pada tabel 3.1 dibawah ini :
Tabel 4. Kode Postur Kerja 3122

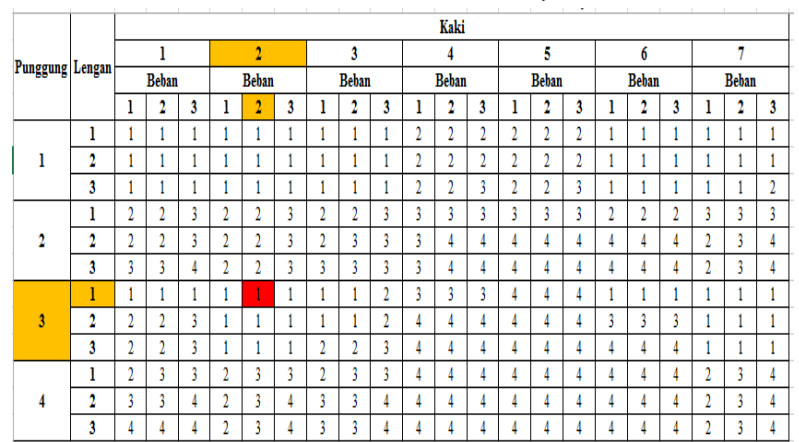

Berdasarkan

pengklasifikasian kategori resiko dan tindakan perbaikan maka aktivitas kerja yang dilakukan oleh pekerja tersebut termasuk dalam kategori resiko pada tingkat resiko (1) yaitu postur kerja yang dilakukan berada dalam posisi normal tanpa efek yang dapat mengganggu sistem musculoskeletal sehingga tidak diperlukan tindakan perbaikan.

Pada pengklasifikasian berdasarkan frekuensi relatif kode posisi hanya 3 digit dikarenakan tidak adanya interval berat beban, sehingga pengklasifikasiannya seperti pada tabel 3.2 dibawah ini :

\section{Tabel 5. Klasifikasi Tingkat Resiko Kode Posisi} 312 Menurut Frekuensi Relatif

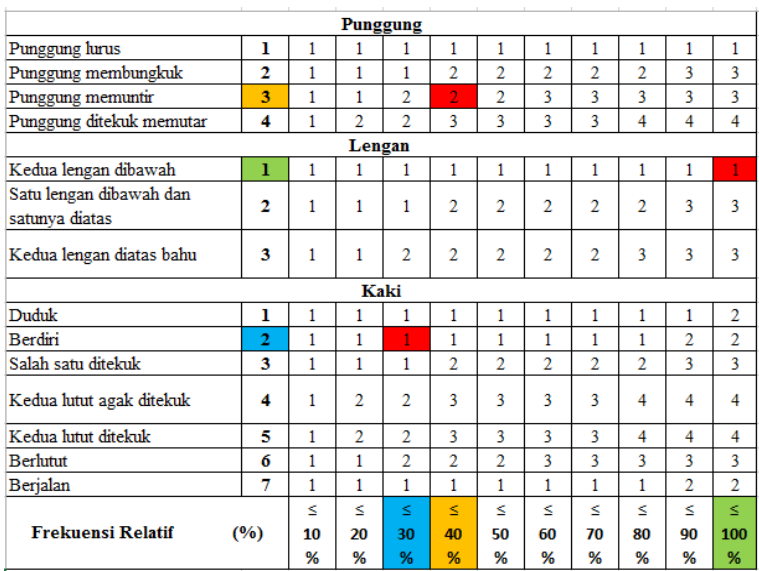

Dari tabel 3.2 di atas menunjukkan bahwa kode posisi untuk punggung adalah 3 , dimana frekuensi relatif dari punggung tersebut $\leq 40 \%$ maka kategori resiko untuk 
punggung adalah 2. Kode posisi untuk lengan adalah 1 , dimana frekuensi relatif dari lengan tersebut $\leq 100 \%$, maka kategori resiko untuk lengan adalah 1 . Kode posisi untuk kaki adalah 2, dimana frekuensi relatif dari kaki tersebut $\leq 30 \%$, maka kategori resiko untuk kaki adalah 1 . Dari hasil perhitungan kategori resiko yang didasarkan pada frekuensi relatif pada masing-masing posisi tubuh tersebut, ternyata posisi punggung berpotensi menyebabkan cedera, posisi lengan tidak ada masalah (aman) dan posisi kaki juga tidak ada masalah (aman).

Setelah dilakukan pengolahan data berdasarkan pengklasifikasian kategori resiko kode posisi OWAS, maka dari 33 postur kerja didapat 16 postur kerja yang tergolong kategori 1 yang berarti postur kerja dalam posisi normal (aman) tanpa efek yang dapat mengganggu sistem musculoskeletal, tidak diperlukan tindakan perbaikan. Serta 8 postur kerja yang tergolong dalam kategori 2, yang berarti postur kerja yang dilakukan berpotensi menyebabkan kerusakan pada sistem musculoskeletal sehingga tindakan perbaikan mungkin diperlukan. Postur kerja dengan kategori resiko kerja dengan tingkat resiko 1 dan 2 dapat dilihat pada tabel 3.3 dibawah ini :
Tabel 6. Rekapitulasi Postur Kerja Kategori 1 dan 2 Pada Ketiga Jenis Pegas

\begin{tabular}{|c|c|c|c|c|c|}
\hline No & Jenis Pegas & Aktivitas & Postur & $\begin{array}{l}\text { Kode } \\
\text { Posisi }\end{array}$ & Kategori \\
\hline \multirow{10}{*}{1.} & \multirow{10}{*}{$\begin{array}{l}\text { Pegas Dukung } \\
\text { K5 }\end{array}$} & \multirow{3}{*}{$\begin{array}{l}\text { 1. Pengangkatan pegas } \\
\text { ke mesin pengujian }\end{array}$} & 1 & 3122 & 1 \\
\hline & & & 2 & 1172 & 1 \\
\hline & & & 3 & 2132 & 2 \\
\hline & & \multirow{3}{*}{$\begin{array}{l}\text { 2. Proses pengujian } \\
\text { pegas }\end{array}$} & 2 & 3122 & 1 \\
\hline & & & 3 & 3122 & 1 \\
\hline & & & 4 & 2122 & 2 \\
\hline & & \multirow{4}{*}{$\begin{array}{l}\text { 3. Pengangkatan pegas } \\
\text { yang telah diuji }\end{array}$} & 1 & 2132 & 2 \\
\hline & & & 2 & 3132 & 1 \\
\hline & & & 3 & 1172 & 1 \\
\hline & & & 4 & 2122 & 2 \\
\hline \multirow{9}{*}{2.} & \multirow{9}{*}{$\begin{array}{c}\text { Pegas Ayun } \\
\text { Dalam (imner) } \\
\text { K5 }\end{array}$} & \multirow{4}{*}{$\begin{array}{l}\text { 1. Pengangkatan pegas } \\
\text { ke mesin pengujian }\end{array}$} & 1 & 2132 & 2 \\
\hline & & & 2 & 3132 & 1 \\
\hline & & & 3 & 1172 & 1 \\
\hline & & & 4 & 2132 & 2 \\
\hline & & \multirow{2}{*}{$\begin{array}{l}\text { 2. Proses pengujian } \\
\text { pegas }\end{array}$} & 2 & 3132 & 1 \\
\hline & & & 3 & 3132 & 1 \\
\hline & & \multirow{3}{*}{$\begin{array}{l}\text { 3. Pengangkatan pegas } \\
\text { yang telah diuji }\end{array}$} & 2 & 1122 & 1 \\
\hline & & & 3 & 1172 & 1 \\
\hline & & & 4 & 2132 & 2 \\
\hline \multirow{5}{*}{3.} & \multirow{5}{*}{$\begin{array}{l}\text { Pegas Ayun Luar } \\
\text { (outter) K5 }\end{array}$} & \multirow{2}{*}{$\begin{array}{l}\text { 1. Pengangkatan pegas } \\
\text { ke mesin pengujian }\end{array}$} & 2 & 1172 & 1 \\
\hline & & & 3 & 2132 & 2 \\
\hline & & $\begin{array}{l}\text { 2. Proses pengujian } \\
\text { pegas }\end{array}$ & 3 & 3132 & 1 \\
\hline & & \multirow{2}{*}{$\begin{array}{l}\text { 3. Pengangkatan pegas } \\
\text { yang telah diuji }\end{array}$} & 2 & 1172 & 1 \\
\hline & & & 3 & 3132 & 1 \\
\hline
\end{tabular}

Dan terdapat 8 postur kerja yang tergolong kategori 3 yang berarti pada postur kerja ini memiliki efek berbahaya pada sistem musculoskeletal sehingga tindakan perbaikan diperlukan segera. Serta terdapat 1 postur kerja yang tergolong dalam kategori 4, yang berarti pada postur kerja ini memiliki efek sangat berbahaya pada sistem musculoskeletal sehingga tindakan perbaikan diperlukan sesegera mungkin.Postur kerja dengan kategori resiko kerja dengan tingkat resiko 3 dan 4 dapat dilihat pada tabel 3.4 dibawah ini: 
Juarni, Ramadhan, M, Analisa Postur Kerja pada Aktivitas Pengujian Pegas dengan Menggunakan Metode OWAS

Tabel 7. Rekapitulasi Postur Kerja Kategori 3 dan 4 Pada Ketiga Jenis Pegas

\begin{tabular}{|c|c|c|c|c|c|}
\hline No & Jenis Pegas & Aktivitas & Postur & $\begin{array}{l}\text { Kode } \\
\text { Posisi }\end{array}$ & Kategori \\
\hline 1. & $\begin{array}{c}\text { Pegas Dukung } \\
\text { K5 }\end{array}$ & $\begin{array}{l}\text { 2. Proses pengujian } \\
\text { pegas }\end{array}$ & 1 & 4122 & 3 \\
\hline \multirow{3}{*}{2.} & \multirow{3}{*}{$\begin{array}{c}\text { Pegas Ayun } \\
\text { Dalam (inner) } \\
\text { K5 }\end{array}$} & \multirow{2}{*}{$\begin{array}{l}\text { 2. Proses pengujian } \\
\text { pegas }\end{array}$} & 1 & 2142 & 3 \\
\hline & & & 4 & 4132 & 3 \\
\hline & & $\begin{array}{l}\text { 3. Pengangkatan pegas } \\
\text { yang telah diuji }\end{array}$ & 1 & 2142 & 3 \\
\hline \multirow{5}{*}{3.} & \multirow{5}{*}{$\begin{array}{c}\text { Pegas Ayun } \\
\text { Luar (outter) } \\
\text { K5 }\end{array}$} & $\begin{array}{l}\text { 1. Pengangkatan pegas } \\
\text { ke mesin pengujian }\end{array}$ & 1 & 2142 & 3 \\
\hline & & \multirow{3}{*}{$\begin{array}{l}\text { 2. Proses pengujian } \\
\text { pegas }\end{array}$} & 1 & 2142 & 3 \\
\hline & & & 2 & 3142 & 3 \\
\hline & & & 4 & 4142 & 4 \\
\hline & & $\begin{array}{l}\text { 3. Pengangkatan pegas } \\
\text { yang telah diuji }\end{array}$ & 1 & 2142 & 3 \\
\hline
\end{tabular}

\section{KESIMPULAN}

Berdasarkan pembahasan pada halaman sebelumnya maka dapat disimpulkan beberapa hal antara lain adalah sebagai berikut :

1. Dari 33 postur kerja berdasarkan penilaian metode OWAS, didapatkan bahwa postur kerja pada aktivitas pengujian pegas yang aman pada sistem musculoskeletal berjumlah 24 postur kerja dan postur kerja yang memiliki resiko pada sistem musculoskeletal berjumlah 9 postur kerja.

2. Untuk memperbaiki postur kerja khususnya pada aktivitas pengujian pegas berdasarkan penilaian metode OWAS, maka perbaikan lebih diarahkan pertama kali untuk memperbaiki posisi kaki dengan menaikkan landasan peletakkan pegas dengan cara penambahan fasilitas kerja berupa meja di dekat mesin pengujian pegas, sehingga pekerjaan dapat dilakukan dengan posisi kaki lurus dan secara otomatis juga akan memperbaiki posisi punggung sehingga tidak membungkuk.

\section{DAFTAR PUSTAKA}

Anggraini, Wresni dan Mulya, Pratama Anda. 2012. Analisis Postur Kerja dengan Menggunakan Metode OWAS pada Stasiun Pengepakan Bandela Karet. Jurnal Sains UIN SUSKA Riau.

Hasan, Ir. M. Iqbal, M.M. Statistik, Edisi Kedua, PokokPokok Materi Statistik 1 (Statistik Deskriptif). Bumi Aksara. Jakarta

Janoko, Bayu, Triyono dan Prasetya Eko. 2014. Analisa Kegagalan Pegas Ulir Pada Bogie. Jurnal Mekanika, Universitas Sebelas Maret.

Nurmianto, Eko. 2004. Ergonomi, Edisi Kedua, Konsep Dasar dan Aplikasinya. PT Guna Widya. Surabaya.

Tarwaka, PGDi.Sc., M.Erg. 2010. Ergonomi Industri, Edisi Kedua, Dasar Dasar Pengetahuan Ergonomi dan Aplikasi di Tempat Kerja. Harapan Press, Solo. 